\title{
WILLIAM BUCHAN: MEDICINE LAID OPEN
}

by

\section{J. LAWRENCE*}

\section{THE AUTHORSHIP OF DOMESTIC MEDICINE}

MEDICAL WORKS for the layman in the eighteenth century reflect the diversity of the contemporary medical doctrines which they implicitly transmitted to the public. These books did however distort the teachings of the schools in a variety of ways: by their use of the vernacular and less technical language; their practical emphasis; through the ingenuity or otherwise of the author; and their tendency to eclecticism. The public acclaim of a particular work did not necessarily indicate the orthodox status of the system it adopted, for example the success of John Wesley's extreme empiricism in his Primitive physic. William Buchan's Domestic medicine was no doubt written for economic reasons as well as for the humanitarian purpose of providing a substitute for the deficiencies of medical care. But besides this, its author saw a useful, even necessary virtue in "laying Medicine more open to mankind". 1 Considering the vast sales of the book, it undoubtedly laid open a particular view of medicine to a large public in an age anxious for education. This view, though diverse in its origins, was ultimately grounded in the intellectual climate of mid-eighteenthcentury Edinburgh.

Domestic medicine was a household guide to diagnosis and therapy. It achieved during its lifespan of one hundred and forty-four years a popularity rivalled only by John Wesley's Primitive physic. First published in Edinburgh in 1769, new editions, reprints and pirated versions appeared every few years in Britain until 1846. There were also several editions in French, Spanish, Portuguese, Italian, German, Russian and Swedish. In America it enjoyed great longevity, for after the first edition was published in Philadelphia in 1771, Domestic medicine continued to appear from a variety of towns and at frequent intervals until its demise at Boston in 1913. Throughout its many variations the basic form of the book remained unchanged. It consisted of two main parts, a general section on the causes of disease and their prevention, and a detailed description of a wide range of disorders. Diseases were grouped under fairly broad headings; none of the more detailed nosologies of the time was adopted.

Domestic medicine was apparently written by two Scotsmen, William Buchan the accredited author, and William Smellie, whose name only appeared as the printer of the first edition. Brief biographies indicate the similar erudition and outlook of these men and help to explain the character of the book.

There is little authoritative material for Buchan's life. He was born in Ancrum,

*C. J. Lawrence, M.B., Ch.B., M.Sc., is a Wellcome Research Student, Wellcome Institute for the History of Medicine, 183 Euston Road, London NW1 2BP.

Medical History, 1975, vol. 19. 


\section{William Buchan: medicine laid open}

Roxburghshire, in 1729. Educated at the local grammar school, he later went to the University of Edinburgh, intending to enter the Ministry. But he transferred his interests to medicine and never completed his theological studies. He seems to have spent about nine years at the university, having devoted a great deal of time to botany, astronomy and mathematics. He left Edinburgh, probably in 1758, having completed his medical education at a time when Edinburgh was the most progressive school in the country. Amongst the more notable of Buchan's teachers were John Rutherford, Robert Whytt, two of the Alexander Monros (primus and secundus) and latterly, William Cullen. Buchan first settled in practice in rural Yorkshire, but in $\mathbf{1 7 5 9}$ he was appointed medical officer to a recently opened branch of the Foundling Hospital at Ackworth, Yorkshire. There he wrote his M.D. thesis De infantum vita conservanda, which was published in Edinburgh in $1761 . .^{2}$ Buchan remained at Ackworth until the following year when he took up practice in Sheffield. He stayed there until 1766 when he returned to Edinburgh. In 1772 he became a Fellow of the Royal College of Physicians of Edinburgh, and when John Gregory died in 1773, Buchan was a candidate for the vacant Chair of the Institutes of Medicine. He failed to achieve this, however, since the appointment was apparently awaiting the graduation of the younger Gregory, who succeeded to the chair in 1778. In this same year Buchan moved to London, where he practised until his death in 1805 . Few other details are known of his life. In 1761 he married into the Dundas family, and thereby became a relative of Sir John Pringle (1707-1782). He had a lifelong interest in popularization, for he wrote several other less successful tracts on health. According to his obituaries he gave popular lectures on Newtonianism, using the apparatus of his late friend, the astronomer and great Newtonian expositor, James Ferguson (1710-1776). ${ }^{3}$ If he did so, it must have been only for a few months. ${ }^{4}$ Buchan was apparently extremely well known in the coffee houses of London and had the final distinction of burial in Westminster Abbey.

William Smellie is better known and his life has been well documented by Kerr in $1811 .{ }^{5}$ Born in Edinburgh in 1740, he was apprenticed to a printer at the age of twelve. Printing remained his trade for the rest of his life, notwithstanding several attempts to enter other fields. In 1760, with Buchan and others, he was a founder member of a Newtonian Society at Edinburgh. A keen botanist, he lectured at the university, and was unfortunate not to attain the Chair of Natural History. He was an original member of the Society of Antiquaries of Scotland. Popularization was in a sense Smellie's occupation. He compiled, edited and contributed to the first edition of the Encyclopaedia Britannica (1771). He wrote a large and successful Philosophy of natural history ${ }^{6}$ and translated Buffon's Natural history. ${ }^{7}$ Smellie had a lifelong interest in medicine, attending lectures at the university whenever possible. A typical Edinburgh polymath of the period, his close friends included David Hume, Lord Monboddo, Lord Kames and Robert Burns. He died in 1795.

That Buchan was not the sole author of Domestic medicine was the opinion of Smellie's biographer, Kerr. Since many of Smellie's letters were burnt at his death, Kerr admitted, "We have no documents now remaining on which to found any estimate of the actual share which Mr. Smellie had in the composition of that work". ${ }^{8}$ The concept of a comprehensive domestic manual was undoubtedly Buchan's, and 


\section{J. Lawrence}

he had considered the idea perhaps as early as 1759 . From that time on Buchan was repeatedly writing to Smellie, encouraging him to give up printing, and to go to Ackworth as an assistant and dispenser, preliminary to medical qualification. Kerr believed Buchan in fact needed help with the book, and wanted to confer on Smellie the office of "literary drudge". The letters justify this opinion to some extent. Smellie however was unable to give up his trade, and, whatever the real reasons for Buchan's importunes, they were certainly a stimulus to Smellie's prodigious medical studies. By 1764 Buchan had written a domestic medicine of some sort, for he wrote to Smellie asking him to make a clandestine trip to Sheffield at the time of printing. His letters certainly indicate he felt in need of help. "Now it is no easy matter you know for a person in practice to be able to find time both for writing and correcting". ${ }^{9}$ Smellie again refused and the work was not printed. Shortly after this Buchan moved to Edinburgh and three years later the book was published. The evidence for authorship at this point is Kerr's unverifiable testimony. Smellie, according to Kerr, definitely corrected the proofs for a fee of one hundred pounds, and Kerr claimed the bill was still extant. ${ }^{10}$ Smellie's son testified for his father that Domestic medicine "was entirely rewritten by him before going to press". ${ }^{11}$ Kerr reported that Smellie had repeatedly mentioned to his friends that the original manuscript of the book was "prodigiously redundant" and that he had compressed it into reasonable bounds. ${ }^{12}$ According to Kerr, many still maintained that the book was written by Smellie alone. Kerr did have an animus against Buchan, since Smellie, who was always in debt, lost money on the unpaid subscriptions for the book. However, Kerr was writing at a time when Buchan's close relatives were still alive, and libel was a subject about which he was extremely sensitive elsewhere in the biography. Smellie's medical studies certainly equipped him for the task of revision, and it seems likely that Buchan wrote an extensive domestic medicine which Smellie compressed, corrected, and to some extent rewrote.

The book itself furnishes evidence of dual authorship. Only the first edition, which differed substantially from the rest, bore Smellie's imprint. The second edition included an enlarged, rewritten and more aggressive introduction. It incorporated new chapters on venereal disease, disorders of the senses and many other minor modifications. The third edition added a dispensatory and in this form, with little further alteration, reached its widest audience. ${ }^{13}$

The significance of the biographical material lies less in the exact contributions of the two men, than in their education; one a qualified physician, the other with extensive medical knowledge, and both widely read in philosophy and the natural sciences. Equally important was their continual contact with the flourishing intellectual life of Edinburgh generally. Because of this cultural background Domestic medicine made a distinctive contribution to the three educational themes running through the book: the rise of popular scientific education; the rebirth of the health movement; and the tradition of domestic handbooks of all kinds.

\section{DOMESTIC MEDICINE AND THE RISE OF POPULAR SCIENTIFIC EDUCATION}

The eighteenth century saw an unprecedented rise in popular education, and science was well represented in both publications and lectures. The intellectual atmosphere 


\section{William Buchan: medicine laid open}

at Edinburgh was particularly favourable for the production of popular works. The societies and lectures that had been instituted in the city derived their intellectual stimulus from a Scottish philosophy that saw the knowledge necessary for human progress not as the prerogative of obscure metaphysics but as being universally accessible and verifiable. This knowledge was seen in turn as an antidote to superstition and blind and excessive enthusiasm. ${ }^{14}$ The most tangible causes for such educational optimism were the discoveries of natural philosophy.

Thus Domestic medicine saw science in these terms and found in medicine particularly, an unexplored area of popular education. "No science lays open a more extensive field of useful knowledge, or affords more ample entertainment to an inquisitive mind. Anatomy, Botany, Chymistry and the Materia Medica, are all branches of Natural History, and are fraught with such amusement and utility, that the man who entirely neglects them has but a sorry claim either to taste or learning." 15 The book therefore deliberately undertook to instruct the literate classes in medicine, both for the delight of the subject itself, and, more important, to counter public gullibility. It was indeed an expression of that "eager didactic impulse to set things right". ${ }^{16}$ Popular enthusiasm was no quixotic windmill, but a real problem, for it was quackery and the more fantastic medical speculations that attracted public support and encouragement. Almost a hundred years previously, Sydenham, referring to his own work, summed up the matter precisely, "Better would it have been for my present fame to have continued some vain and useless speculation."17

Domestic medicine's formulation of this philosophy of popularization undoubtedly owed much to the works and personal influence of John Gregory, who was one of the most articulate spokesmen of the Edinburgh school. Gregory came to Edinburgh from Aberdeen in 1766, that is after a preliminary version of Domestic medicine had been written. But some of Gregory's ideas had already been published, and in Edinburgh he was an intimate friend of Buchan and Smellie. Gregory was firmly of the opinion that acquainting the layman with medicine would promote the growth of medical knowledge and help to counteract quackery. As early as $\mathbf{1 7 6 5}$ he had remarked "No science ever flourished while it was confined to a set of men who lived by it as a profession." 18 Five years later in his more famous Observations on the duties and offices of a physician he elaborated on this opinion. This view must have had a fairly unfriendly reception from some quarters for, in the next enlarged edition he admitted "I have the misfortune to differ from many of my brethren on this subject." 19 Domestic medicine echoed these views with assurance and consistency; the first edition of 1769 repeated Gregory's earlier remark "No art ever arrived at any considerable degree of improvement so long as it was kept in the hands of a few who practised it as a trade". ${ }^{20}$ The second edition of 1772 and subsequent ones incorporated the phrase "laying medicine open", which had occurred in Gregory's recently published Observations of 1770 . Buchan, who almost certainly revised the later editions, also recognized that he was guilty of a heresy, "By the more selfish and narrow-minded part of the Faculty the performance was condemned." ${ }^{21}$ Even so, Buchan's zeal for reformation was perhaps more excessive than Gregory would have wished, condemning any element in professional practice, including the use of Latin, that supposedly blurred the distinction between quacks and qualified physicians. 


\section{J. Lawrence}

Domestic medicine had, at times, more in common with the radical criticism in Wesley's Primitive physic than with Gregory's Observations.

This educational philosophy was not without the threat of an inconsistency. The belief in science led the protagonists to support the profuse knowledge necessary to a physician. This in turn, it might be added, was a defence of their own status. But their desire to lay medicine open led to the playing down of everything but the purely empirical aspects of practice. Gregory postulated, "In order therefore to be qualified for the practice of physic, a variety of branches of knowledge seemingly little connected are extremely necessary". ${ }^{22}$ But elsewhere, decrying obscure philosophy and advocating increased lay involvement, he noted that improvements in medicine were usually the result of "accidental discoveries" or "happy natural sagacity". ${ }^{23}$ In Domestic medicine this gulf widened. Although applauding the basic sciences, it unashamedly noted, "The knowledge of diseases does not depend so much upon scientific principles as many imagine. It is clearly the result of experience and observation. ... Hence sensible nurses and other persons who wait upon the sick often know diseases better than those who have been bred to physic". This was coming dangerously close to the anti-intellectualism of Wesley's Primitive physic, a denial of the value of the basic sciences to medicine and an insidious attack on an élitist status for the medical profession. Buchan sensed this for he immediately added, "We do not however mean to insinuate that a medical education is no use". ${ }^{24}$ Those who objected to Gregory's opinions and Domestic medicine no doubt felt there was justification.

This minor inconsistency was a necessary corollary of overstating the case. It was also a reflection of the still tenuous link between the basic sciences and medical practice. In general, medical advance was seen by Gregory as a result of the application of a scientific method by a qualified profession actively supported and encouraged by the informed layman. The scientific method for the Edinburgh school, and thus Gregory, was inevitably Baconian. Gregory clearly delineated this approach in the Observations with the usual attacks on speculation and uncritical empiricism. He stressed the necessity for low-level induction and experimental proofs. The importance of Gregory is that his mistrust of systems was carried over into his practice to a large extent. He cautioned Cullen against excessive speculation, and though not mentioning him by name attacked a "late celebrated professor" who was probably Boerhaave. ${ }^{25}$ His own Elements of the practice of physic ${ }^{26}$ was comparatively free from the more excessive speculations of the time. The introduction to the second and subsequent editions of Domestic medicine drew extensively on Gregory's Observations in order to justify its inevitable praise of the priority of experience and the barrenness of hypothesis. It lacked however the subtlety of Gregory's analysis, seeing observation as an end in itself and making no distinction between chance occurrence and experimentally tested results. The picture of medicine the work laid open, of course, depended far more on the presentation of clinical material than the customary homage it paid to experience in the introduction. Probably influenced by Gregory's own practice it conspicuously avoided controversial material. Naturally it accepted a general conceptual framework of human physiology, the division of the body into fluids and solids, diseases of the humours and those of the fibres such as rigidity and laxity, and a scheme of causation which was still largely bound to the non-naturals. ${ }^{27}$ But it 


\section{William Buchan: medicine laid open}

did not go beyond this to the chemical composition of the blood or the haemodynamics of inflammation. Buchan brushed aside the body-soul question as unsolved and irrelevant, notwithstanding his deep admiration for Robert Whytt (1714-1766) the Edinburgh physician whose views on the coextension of body and soul had involved him in a lengthy controversy with Haller. Inevitably a popular work avoided excessive technical description, though some authors, such as Brookes, ${ }^{28}$ and Lynch, ${ }^{29}$ included what they saw as necessary theory. The requirements of popularization apart, the authors of Domestic medicine were mistrustful of medical systems. Buchan had formed an early distaste for theory "Cullen is clever and does not want for genius, but has his head full of theory and vague hypothesis". ${ }^{30}$ Smellie with obvious approval, wrote of Gregory, "He considered that a rational theory of medicine had never yet been devised". ${ }^{31}$ Buchan thus chose to emphasize clinical description and regimen, rather than proximate causes and specific therapy.

\section{THE HEALTH MOVEMENT}

After many fluctuations of popularity the ancient concern for hygiene was vigorously reborn as the health movement. This was an expression of the didactic impulse, and one manifestation of it was a profusion of literature aimed at the individual, in the Utopian hope that widespread education would improve the health of the community in general. The movement was powerful but short-lived, Sinclair's extensive bibliography of hygiene listed almost 1900 publications in Europe, a great many of which had been produced during the eighteenth century. ${ }^{32}$ Buchan was committed to this movement in his concern with prophylaxis and regimen, Domestic medicine contained rules for the healthy as well as the sick. Works on health were usually based on the six non-naturals, though during the eighteenth century they were gradually subsumed under wider classifications. The essays of Cheyne ${ }^{33}$ and Mackenzie $^{34}$ were probably the most successful expositions in English of these accessory causes of disease. Both Buchan and Wesley acknowledged their debt to Cheyne. But Buchan's handling of the same material fifty years later showed a distinct shift of emphasis from Cheyne's more traditional account. Cheyne's essay was divided into the six classical headings: air, meat and drink, sleeping and watching, exercise and quiet, evacuations and obstructions, and the passions, but he also added a chapter on miscellaneous observations. He made no comments about society generally but formulated precise rules by which a gentleman should conduct his life. These were justified by extensive correlation with physiological change. The medical theory was a detailed exposition of Cheyne's own version of corpuscular philosophy, and tended at times to obscure the didactic nature of the work. ${ }^{35}$

Buchan, though not totally abandoning the rigid framework of the non-naturals, did not refer to them as such. He introduced a strong social as well as an individual emphasis. But the most significant reflections of change were the new chapters on infection and cleanliness. The term "infection" was never precisely defined in the work, and was used synonymously with "miasma" and "contagion". The eighteenthcentury concept of infection was little different from the medieval one, and Domestic medicine exemplified all the older beliefs. It described the origin of infection in stagnant air, and its association with increasing putrescence. The book did not distinguish 


\section{J. Lawrence}

between offensive odours and infection, and consequently confused deodorants and disinfectants. Though the concept of infection had changed little, the fight against it had intensified during the eighteenth century. Buchan relied on the aphorism "most diseases are infectious." ${ }^{36}$ This was far removed from the academic approach of Cheyne.

The emphasis in Domestic medicine on prevention of infection was to some extent a reflection of the wide influence of Sir John Pringle's work and his own personal reputation. Buchan actually dedicated the book to him. Pringle's Observations on the diseases of the army ${ }^{37}$ made almost revolutionary comments on the importance of cleanliness, ventilation, removal of excrement, the prevention of over-crowding and the need for clean clothing among the troops. All these recommendations were repeatedly expressed in Domestic medicine in relation to homes, hospitals and places of work. Though the tone at times was rather Utopian, the book was a real source for the diffusion of Pringle's ideas.

Buchan's ideas for the implementation of these recommendations illustrates another aspect of the health movement. Elsewhere in Europe differing political philosophy resulted in the early development of advanced ideas of medical police, such as are found for instance in the works of the German Johann Peter Frank (1745-1821). In Britain the energy of the health movement was directed either at the education of the individual, or through the private enterprise of humanitarians. But Buchan used Pringle's ideas as a demand for a wide range of laws for community protection. Many of these laws in fact existed, and isolated individuals in the eighteenth century, notably John Bellers, had drawn up extensive plans for legislatively controlled health services. ${ }^{38}$ But the concept was in many ways alien to British thought, as Buchan recognized "The importance of a proper medical police is either not understood or very little regarded". ${ }^{39}$ The phrase "medical police", probably first used by Wolfgang Thomas Rau in 1764, had obviously become accepted currency in some British circles. ${ }^{40}$

As Temkin has shown, the intensification of the fight against infection was a consequence of other factors besides industrialization. ${ }^{41}$ It was also the result of a changing concept of personal cleanliness. During the eighteenth century the idea of cleanliness, besides its aesthetic connotations, was becoming associated with the concept of personal filth as a cause of disease. Shortage of water made cleanliness difficult during that century, but even so, washing was not generally regarded as necessary. ${ }^{42}$ Domestic medicine, though equating cleanliness with politeness and civilization, also noted, "If dirty people cannot be removed as a common nuisance, they ought at least to be avoided as infectious". ${ }^{43}$ As a consequence of this the book included what are today regarded as fundamental rules of hygiene, such as regular bathing and washing clothes. It emphasized that when dealing with the sick, hands should be washed, bed linen should be frequently changed, and the rooms kept well ventilated and free from relatives. In Scotland it was customary for large numbers of relatives to visit the sick, and windows when they existed usually did not open. ${ }^{44}$ This sort of advice became increasingly common in the health movement literature of the eighteenth century, and Domestic medicine was one of the earliest works to reflect the change. For the poor of course most of the advice was hopelessly im- 


\section{William Buchan: medicine laid open}

practical and confused with the idea of legislation. But a book with such wide readership must have played some part in changing standards of cleanliness, and promoting the idea that parochial laissez-faire was unequipped to deal with the demon of public health.

\section{DOMESTIC MEDICINE AND THE TRADITION OF HOUSEHOLD REMEDIES}

Though Domestic medicine was a guide to hygiene, it was primarily an account of a wide range of specific diseases and their treatment. Both these factors resulted in a comprehensiveness unrivalled by most earlier popular works. Herbals and receipt books lacked the detailed clinical descriptions, and other more adventurous attempts were still either too limited, ${ }^{45}$ too technical, ${ }^{46}$ or outmoded by revision of the pharmacopoeia. ${ }^{47}$ Domestic medicine had been anticipated in France by Tissot's Avis au peuple ${ }^{48}$ and was actually based on this, as Buchan freely admitted. He had a high regard for Tissot and called him "learned and humane". ${ }^{49}$ They had much in common, not least of which was the influence of Rousseau on their works. ${ }^{50}$ Tissot was a great admirer of Rousseau, much to the annoyance of Haller, ${ }^{51}$ and Buchan's chapter on child care owed a great deal to Rousseau's Emile. Buchan followed closely Tissot's clinical descriptions and therapy, though he paid far greater attention to prophylaxis and the details of personal hygiene. Tissot's work went through several English editions, but Kirkpatrick's prolix translation must have diminished its ability to compete. It was in some ways a superior work to Domestic medicine. Buchan, when relying on his own clinical experience, lacked the acumen of Tissot. This was often the result of his curiously ambivalent vision of the layman. His buoyant optimism in scientific medicine led him to deride the "ignorant rustic" and his "mysterious remedies". ${ }^{52}$ " But, too often in attacking professional esotericism, it was the observational powers of the layman he deified "In some parts of the country the peasants apply to a recent bruise a cataplasm of fresh cowdung", a remedy he had frequently seen and "never knew to fail". ${ }^{53}$ At other times the cautious approach to therapy was abandoned altogether. Quicksilver up to the weight of a pound was recommended for inflammation of the intestines, and if more was given he suggested to "hang up the patient by the heels, in order that the quicksilver may be discharged by the mouth". ${ }^{54}$ Tissot specifically condemned heroic therapy in this condition..$^{55}$ Both the above remedies were retained in the nineteenth-century editions.

OCCUPATIONAL HAZARDS IN THE EIGHTEENTH CENTURY

Domestic medicine did, however, broaden the scope of Tissot's work in another way. The inclusion of a chapter on industrial disease was a conspicuous indication of a new direction in medical thought. English translations of Ramazzini's De morbis artificum diatriba of 1700 had appeared in $1705^{56}$ and $1746,,^{57}$ but apart from interest in the army and navy there had been little original investigation of industrial disease in the early eighteenth century. There had been almost no attempt to draw public attention to the medical consequences of working conditions. Apart from a brief mention in Lynch's book ${ }^{58}$ of coal mines as an instance of contaminated air, no other popular work had included the subject. The periodical press too had largely ignored it. Most of Buchan's descriptions were taken from Ramazzini, highly condensed and lacking the astute observation and compassionate style of that writer. 


\section{J. Lawrence}

The short section on miners' diseases illustrates well the strain of naive optimism in eighteenth-century humanitarian thought. Early editions of Domestic medicine briefly listed the disorders of miners and recommended a regimen. Later editions dealt with wider aspects of the problem, and noted that fire damp, a problem associated with the deeper coal mines of the eighteenth century, could be removed by explosions, and that choke damp should be expelled by adequate ventilation. Though little thought was given to the safety of miners, these were problems the technology of the day was quite unable to handle. ${ }^{59}$ Miners themselves, Buchan noted, ought never "to continue too long at work". ${ }^{60}$ This salubrious recommendation took no account of the system of labour in the mines. In Scotland, for instance, miners still worked under a system of bondage. ${ }^{61}$ But in spite of this, the book was drawing the attention of the urban middle class to an isolated and often unknown community, usually represented in contemporary accounts as a degraded example of humanity.

The section on industrial disease included a short passage on the diseases of sailors which is a lively reflection of the conflict over cures for scurvy. It demonstrates well the difficulty contemporary physicians had in evaluating a mass of conflicting evidence. James Lind's Treatise of the scurvy (1753) would almost certainly have been known to Buchan, for Lind was an Edinburgh graduate. Buchan first stressed that hardship, spirit drinking and poor conditions were all contributory to the diseases of sailors, and, together with Pringle, held that the putrescence of salted provisions caused scurvy. As a first line of treatment he insisted citrus fruits be given, even though some authors had denied their value altogether. ${ }^{62}$ But with his customary caution Buchan added that, in their absence, the traditional remedies of vinegar and chemical acids could be used. Lind had specifically noted that elixir of vitriol as a gargarism improved the condition of the mouth but "perceived otherwise no good effect from its internal use upon the other symptoms". ${ }^{63}$ It was no easy task for the ordinary practitioner to recognize the importance of Lind's work, which was but one of a number of publications advocating a specific remedy. The authorities were inundated with nostrums; the Admiralty was especially interested in the pamphlet of David Macbride, which showed how scurvy might be cured without a fresh vegetable diet by the use of an infusion of malt called "wort". ${ }^{64}$ Sir John Pringle had been particularly impressed by this supposed cure. It is therefore hardly surprising to find Buchan noting that "Wort is very wholesome and found to be an antidote against the scurvy". ${ }^{65}$ This recommendation was carried into the nineteenth-century editions, even after citrus fruits became official for the Royal Navy in $1795 .{ }^{66}$ It is a facile task to decry eighteenth-century physicians for not recognizing the significance of Lind's work. Domestic medicine well illustrates the sort of pressures that prevented objective judgement; the evidence of tradition, personal pressures, and not least a circumspect attitude to the proposal of a single, universally effective remedy.

The whole section on industrial disease was inferior in many ways to the rest of the work. The descriptions were based on secondary sources rather than first-hand clinical observations, and the whole was interspersed with nugatory pronouncements on complex social questions. But its inclusion can be measured in other ways. First, it had a didactic function not served by other works. The innovation was soon taken up; B. Cornwell's Guardian of health of 1784 (London, The Author) included a section 


\section{William Buchan: medicine laid open}

on industrial disease. Second, it can be seen as an indication of a nascent medical interest. The physiology of social class, neglected except for the military, was to attract increasing attention from the profession and give rise later to the work of Thackrah and others.

\section{DOMESTIC MEDICINE AND THE CLINICAL APPROACH}

Detailed clinical descriptions were the obvious method of assisting the layman in his diagnosis and treatment of disease. Curiously enough this method had been used only infrequently in previous popular works, and their descriptions were often incomplete and not specific enough to be of any value. Tissot was the first to utilize the full potential of accurate clinical description. That Buchan recognized Tissot's method as valuable was surely a reflection of the importance of bedside teaching at Edinburgh, which had been inherited from Boerhaave and the Leyden school. Buchan described a wide variety of diseases including surgical and obstetrical disorders. Early editions incorporated fairly quickly the results of promising research as well as some less durable fashions in treatment. It is interesting to see the lead of cider presses cited as a cause of colic in the edition of 1772. Baker's account of this illness was still not accepted in some quarters as late as $1780 .{ }^{67}$ The enthusiasm for the use of hemlock following von Stoerck's claims ${ }^{68}$ resulted in the inclusion of this for the treatment of schirrus or cancer in the same edition. This probably derived from Tissot. Buchan included a condensed account of Whytt's description of tuberculous meningitis, ${ }^{69}$ though by the omission of a time scale its precision was somewhat invalidated. Again it was the second edition that incorporated a note on Home's attempts to inoculate against measles. ${ }^{70}$ Buchan was sceptical of these results and even today they are the subject of controversy. ${ }^{71}$ But there was obviously a great deal more unpublished work on inoculation, to judge from Buchan's account. At any rate he saw in it another justification for an optimistic view of medical progress. However this was a long-term optimism and served to check any blind enthusiasm for panaceas. Electricity was allotted only a limited place in the treatment of palsy, whereas Wesley had said of it "Certainly it comes the nearest an universal Medicine of any yet known in the world". ${ }^{72}$

The predominant conception of disease which the work publicized was the doctrine of the healing power of nature. Nearly all the other physicians mentioned in the work were disciples of some particular formulation of this doctrine. Through the influence of Boerhaave, Sydenham's praise of the healing power of nature was widely respected by British physicians. The authorities on fever, from whom Buchan borrowed extensively, such as Pringle and Huxham, recognized fever as the healing endeavour of nature. Buchan adhered to this conception. "Fever is only an effort of nature to free herself from an offending cause". ${ }^{73}$ Stahl's animism, which was the epitome of the doctrine of the healing power of nature, found fertile soil in Britain and had been incorporated by Cheyne into his own variety of iatrophysics. ${ }^{74}$ Tissot too was an advocate of regimen rather than active therapy, an attitude derived from the Hippocratism of Montpellier. The pervasiveness of the doctrine in Domestic medicine is seen in the acceptance of teachings that had been rejected elsewhere. It regarded spontaneous haemorrhage as a most efficacious cure of disease, and it still enunciated 


\section{J. Lawrence}

the ancient doctrine that haemorrhoidal flux cured melancholy. ${ }^{75}$ The therapy Buchan advocated was not wholly based on regimen, but this was the predominant concern. Following Tissot, he advised bleeding, purging and the use of setons in certain conditions, though perhaps more frequently. But their use was limited and even conservative by some contemporary standards. Mercury too only found limited application, and, with the exception of millipedes as a cure for whooping-cough, the more exotic animal remedies were avoided. In more concrete form, Buchan's whole approach is illustrated by the example of smallpox and the advocacy of inoculation.

The cause, treatment and prophylaxis of smallpox was a controversial issue in the eighteenth century, and Buchan made a characteristic contribution to the arguments. He devoted little space to the cause, though consistent with his general approval of a Spartan existence, he endorsed the common view that smallpox was the concomitant of a more luxurious way of life. The causal agent was attributed in a footnote to an infectious virus or poison. Vestiges of the innate seed theory, which the theory of contagion replaced, still lingered, for he remarked that smallpox was so prevalent "it has become in a manner constitutional". ${ }^{76}$ Buchan included a brief but lucid account of the symptoms and major complications, but avoided the finer distinction into types such as warty, crystalline and bloody found in more academic works. ${ }^{77}$ The lucidity was enhanced by being purely descriptive, and not correlating clinical signs with the state of the humours, or the movement of the morbific material. Buchan then devoted a great deal of space to regimen. The aim of this was familiarly expressed as assisting or not disturbing the operations of nature. The cool regimen of Sydenham was described, but Buchan's achievement was the attention he paid to details of hygiene neglected by other authors. In the case of smallpox the culprit was the "strong" and "vulgar prejudice" against keeping the sick clean, and overcrowding them: "A very dirty custom prevails among the lower class of people, of allowing children in the smallpox to keep on the same linen during the whole period of that loathsome disease". ${ }^{78}$ This was not a fragmentary observation, the unhygienic nature of the practice was explained at length. The prejudice was in fact not just the prerogative of the vulgar, it was endorsed by the medical profession, "As for the Nastiness and Stench caused by the purulent Matter, it was never yet observ'd to do the Sick any harm". ${ }^{79}$ Even Huxham only modified this teaching: "It is of no small Advantage at this time of the Disease to shift the Linnen of the Sick, which is now grown exceedingly foul, stiff and stinking, and become vastly uneasy to them". ${ }^{80}$ By "this time", he meant the period of incrustation, that is, some time between the tenth and fourteenth day. Of course for the poor, the advice was a mockery, but for those who could afford such extravagances, Domestic medicine was an important medium for the transmission of these ideas.

Smallpox, with no specific therapy, inevitably had a variety of "cures". Boerhaave's suggestion of mercury and antimony resulted in their having many adherents. ${ }^{81}$ Both James's fever powder and Berkeley's tar water had their protagonists. Orthodox therapy, that denied any specific, varied in its enthusiasm. Mead was perhaps one of the most energetic practitioners. He advised "large and reiterated bleedings", 82 plus an array of emetics and purgatives. At the popular level Tissot and Wesley advised nothing outside the cool regimen. Buchan saw no value in any specific and, probably 


\section{William Buchan: medicine laid open}

following Huxham, advised therapy only for complications, such as moderate bleeding for plethora, and clysters and the bark in the malignant form of the disease.

In the light of the other opinions expressed by Buchan, it is not surprising to find him a supporter of inoculation. Its advocacy by the philosophists and the campaigning of the much-admired Tissot had by this time invested inoculation with an ideological aura. For Buchan it became a tendentious weapon in the fight against medical esotericism. Inoculation, as Buchan acknowledged, had triumphed with remarkably little turbulence in Britain, "It is still however far from being general, which we have reason to fear will be the case, as long as the practice continues in the hands of the Faculty". This remark was the preface to an assault on "the fears, the jealousies, the prejudices and the opposite interests" of the profession, and a plea for the use of lay inoculators in a practice requiring only "common sense and prudence". The intransigence of the profession to laying medicine open had led to inoculation being surrounded with "extraordinary secrets or nostrums." 83 This view came close to that of Wesley who saw the ritual of medicine as a deliberate conspiracy to keep healing out of the hands of the layman. In fact the main reason for the failure of general inoculation was the cost of the procedures. ${ }^{84}$ The book recognized this, and consistent with its demands for legislative reform advocated the appointment of lay inoculators so that the poor might receive the service free. As a corollary of the belief in the simplicity of the procedure the book denied the need for any preparation, a subject of much controversy. Buchan recommended the technique of affixing a thread soaked in variolous material to the arm, without any scarification. This perhaps derived from the old Scottish practice of inoculating children "by tying worsted threads wet with the pocky matter round their wrists" ${ }^{85}$ It is impossible to assess any influence Domestic medicine may have had in spreading the practice of inoculation. But such a widely read and respected work must have played some part in encouraging the practice, especially in Scotland. Vaccination on the other hand only received a cautious welcome in a footnote in 1803 , and only achieved equal status with inoculation in the edition of 1809.

\section{A POPULAR IMAGE FOR MEDICINE IN THE EIGHTEENTH CENTURY}

Buchan had laid open an image of medicine and science generally, which was constructed by this method and from these diverse sources. The image was both overtly explained and embodied in his work. Medicine was a cause for qualified optimism, and he pictured medicine in its metamorphosis from an esoteric practice allied to the occult into a true sister of the new philosophy. This by and large was a view he shared with the age. This view committed him to proclaiming medicine as founded on the basic sciences, but he unintentionally demonstrated that this was more expected than justified. Buchan offered no monistic solution, and was quick to point out the speculative nature of much medical knowledge and compare its failure with physics. On this basis he attacked the dead weight of tradition in medicine as a restraint to progress. But by embodying an approach which gave priority to clinical description and regimen the book maintained a discreet grip on the ancients. Out of this image of medicine emerged a picture of scientific method generally, which was inevitably derived from Bacon. Buchan saw observation and experience as the only 


\section{J. Lawrence}

certain method of acquiring true scientific knowledge. Though he seemed almost to consider that the accumulation of random information by the layman was as valuable as controlled experimental enquiry, this notion of science was purely classificatory, and more suited to those eighteenth-century observers who delighted in the tireless collection of minutiae, "counting the little segments of the auditory membrane of certain fish, or in measuring if you please, the distance that a louse is able to leap." 86 But such a public image for science was immeasurably useful, serving to encourage public support for more pedestrian observation and a more sceptical view of the extremes of speculation and universal panaceas.

Domestic medicine's popularity is evidenced by the number of editions that were published, particularly in Scotland where it outsold all competitors. "Scarcely a cottage but what contains on its shelf the Domestic Medicine". ${ }^{87}$ Not only was it widely owned but used "He [the schoolmaster] was very useful in the parish, for he could let blood and was a daily reader of 'Buchan's Domestic Medicine', all whose instructions he rigidly, and often successfully practiced". 88 Professional reaction to the book generally seems to have been indifferent. It received few reviews, the Scots Magazine reprinted three paragraphs from the preface of the second edition without comment. ${ }^{89}$ Only the Universal Magazine showed interest, and significantly chose to approve of it for bringing "down physic to the limit of common sense" and "stripping the healing art of its mysterious form".90 It is interesting that Catherine the Great, ostensible patroness of Enlightenment philosophy, sent Buchan a gold medal.

As Domestic medicine survived into later editions it was inevitably surpassed by other works, many of which owed much to it. Thomas Beddoes criticized the book, for he felt a knowledge of the basic sciences was indispensable to any practice of medicine. His readers would have had no doubt as to which book he was referring. "Of one of these dangerously absurd publications the title announces a dispensatory for the use of private practitioners". ${ }^{91}$ But Beddoes' inclusion of too much basic science in his own Hygēia rendered it useless for practical application. Reece criticized Buchan for his failure to revise later editions. There was some truth in this, but Reece was also motivated by the need to discredit the strongest competitor to his own Practical dictionary of domestic medicine. ${ }^{92}$

By the end of the Napoleonic Wars Domestic medicine had become the aged celebrity of popular medicine. It made frequent reappearances in the same style that had served the eighteenth century. In America it was reduced to the status of a doubleact with a treatise on farriery. ${ }^{93}$ There had been minor revision but the bulk of the material remained the same between the first edition of 1769 and the last English edition of 1846. Many of the clinical descriptions were still valid, but the underlying humouralism was becoming antiquated. Gradually it became as much of an anachronism as had the works it had originally replaced. But any estimate of professional-public relations in the late eighteenth century, and public attitudes to medicine generally, cannot ignore the influence of such a widely read work.

\section{REFERENCES}

1. William Buchan, Domestic medicine, 3rd ed., London, Strahan \& Cadell, 1774, p. xxi. It was the 2nd edition of 1772 which first used this phrase but I shall refer throughout to the third edition as this was the one which underwent little subsequent modification. 


\section{William Buchan: medicine laid open}

2. In $\mathbf{1 7 7 5}$ on the recommendation of Buchan, Jean-Paul Marat, the French revolutionist obtained the degree of M.D. from the University of St. Andrews. See J. Gray, History of the Royal Medical Society 1737-1937, Edinburgh University Press, 1952, p. 72.

3. Gentleman's Mag., 1805, 75, part 1: 287. European Mag., 1805, 47: 168.

4. See E. Henderson, Life of James Ferguson, Edinburgh, A. Fullarton, 1867, p. 453.

5. R. Kerr, Memoirs of the life, writings and correspondence of William Smellie, 2 vols., Edinburgh, John Anderson, 1811.

6. William Smellie, The philosophy of natural history, 2 vols., Edinburgh, The heirs of Charles Elliot, 1790-99.

7. G. L. C. Buffon, Natural history, general and particular, translated with notes and observations by William Smellie, 9 vols., Edinburgh, 1781.

8. Kerr, op. cit., note 5 above, vol. 1, p. 263.

9. Ibid., letter from Buchan to Smellie [Sheffield, c. 1764], vol. 1, p. 259.

10. Ibid., vol. 1, p. 263.

11. Ibid., letter from A. Smellie to R. Kerr, 1810, vol. 1, p. 7.

12. Ibid., vol. 1, p. 223.

13. Though the authorship is disputed, for stylistic reasons I shall regard Buchan as the sole author.

14. See G. Bryson, Man and society, the Scottish inquiry of the eighteenth century, New Jersey, Princeton University Press, 1945, pp. 1-29.

15. Buchan, op. cit., note 1 above, p. xvii.

16. Carl L. Becker, The heavenly city of the eighteenth century philosophers, New Haven, Yale University Press, 1970, p. 39.

17. Thomas Sydenham, Works, translated by R. G. Latham, 2 vols., London, The Sydenham Society, 1848-1850, vol. 1, p. 23.

18. [John Gregory], A comparative view of the state and faculties of man with those of the animal world, London, J. Dodsley, 1765, p. 78.

19. John Gregory, Lectures on the duties and qualifications of a physician, London, W. Strahan \& T. Cadell, 1772, p. 197.

20. Buchan, op. cit., note 1 above, 1st ed., Edinburgh, Balfour, Auld \& Smellie, 1769, p. 8.

21. Ibid., 3rd ed., p. v.

22. [John Gregory], Observations on the duties and offices of a physician, London, W. Strahan \& T. Cadell, 1770, p. 66.

23. Gregory, op. cit., note 18 above, p. 46.

24. Buchan, op. cit., note 1 above, p. 144.

25. Gregory, op. cit., note 18 above, p. 7.

26. John Gregory, Elements of the practice of physic. 2nd ed., London, 1774.

27. The six non-naturals were the categories of factors to which human beings were unavoidably exposed, and on their use or abuse depended health or disease. The usual classification in English was: air, food and drink, sleeping and watching, motion and rest, evacuation and repletion, passions of the mind. The list stems from Galen, though not the term "non-natural" nor the phrase "six non-naturals". See L. J. Rather, "The "six things non-natural": A note on the origins and fate of a doctrine and a phrase', Clio. Med., 1968, 3: 337-347.

28. Richard Brookes, The general practice of physic, London, J. Newbery, 1751.

29. Bernard Lynch, A guide to health through the various stages of life, London, The author, 1744.

30. Kerr, op. cit., note 5 above, letter from Buchan to Smellie 1762, vol. 1, p. 242.

31. William Smellie, 'The life of John Gregory', in Literary and characteristical lives, Edinburgh, Alex Smellie, 1800, p. 95.

32. Sir John Sinclair, The code of health and longevity, Edinburgh, A. Constable, 1807, vol. 2.

33. George Cheyne, An essay on health and long life, London, G. Strahan \& J. Leake, 1724.

34. James Mackenzie, The history of health and the art of preserving it, Edinburgh, W. Gordon, 1758. 


\section{J. Lawrence}

35. Cheyne's concept of matter varied in each of his publications and was highly coloured by his religious beliefs. Early in his career he was an enthusiast for the iatromechanical school of which Archibald Pitcairne was the chief British representative. Increasingly influenced by Newton's work, his later descriptions included interparticulate forces, though he continued to rely on particle size, shape, corrosiveness etc. ... . See Robert E. Schofield, Mechanism and materialism, British natural philosophy in the age of reason, New Jersey, Princeton University Press, 1970, pp. 57-62.

36. Buchan, op. cit., note 1 above, p. 113.

37. Sir John Pringle, Observations on the diseases of the army in camp and garrison, London, A. Millar \& D. Wilson, 1752.

38. John Bellers, An essay toward the improvement of physic, London, Assigns for J. Sowle and J. Morphew, 1714.

39. Buchan, op. cit., note 1 above, p. viii.

40. See G. Rosen, A history of public health, New York, M.D. Publications, 1958, p. 161.

41. O. Temkin, 'An historical analysis of the concept of infection', in Studies in intellectual history, Baltimore Md., The Johns Hopkins Press, 1953, pp. 123-147.

42. Swift made this point abundantly clear in his Directions to servants and in the description of the Yahoos in Gulliver's travels.

43. Buchan, op. cit., note 1 above, p. 108.

44. See M. Plant, The domestic life of Scotland in the eighteenth century, Edinburgh University Press, 1952, pp. 36, 223.

45. See, for instance, J. Hill, The family practice of physic, London, The author, 1769, or [Anon], The family guide to health, London, J. Fletcher, 1767.

46. See, for instance, Theophilus Lobb, A compendium of the practice of physic, London, J. Buckland, 1749; or Brookes, op. cit., note 28 above, and Lynch, op. cit., note 29 above.

47. See, for instance, P. Woodman, Medicus novissimus: or the modern physician, London, A. Ward \& F. Jackson, 1722. This was a clear account of a wide range of diseases, but for epilepsy the author recommended moles, earthworms, dung of peacocks, frogs' livers and blood of hunted hare.

48. S. A. D. Tissot, Avis au peuple, Lausanne, F. Grasset, 1761.

49. Buchan, op. cit., note 1 above, p. 653.

50. Rudolf von Gerhard, 'Jean-Jacques Rousseau (1712-78) und die Medizin', Sudhoffs Arch. Gesch. Med. Naturw., 1969, 53: 30-67.

51. See C. Eynard, Essai sur la vie de Tissot, Lausanne, M. Ducloux, 1839, pp. 85-88.

52. Buchan, op. cit., note 20 above, p. xiii.

53. Ibid., 3rd ed., p. 632.

54. Ibid., p. 320.

55. Tissot, op. cit., note 48 above, p. 336.

56. Bernardino Ramazzini, $A$ treatise of the diseases of tradesmen, written in Latin and now done in English, London, Andrew Bell, 1705.

57. Bernardino Ramazzini, Treatise on the diseases of tradesmen, newly translated with a preface and appendix by Dr. James, London, Thomas Osborne, 1746.

58. Lynch, op. cit., note 29 above, p. 70.

59. G. Rosen, The history of miners' diseases, New York, Schuman, 1943, pp. 141-146.

60. Buchan, op. cit., note 1 above, p. 41.

61. H. Hamilton, An economic history of Scotland in the eighteenth century, Oxford, Clarendon Press, 1963, p. 367.

62. See, for instance, Charles Bisset, $A$ treatise on the scurvy designed chiefly for the use of the British Navy, London, R. and J. Dodsley, 1755. This work recommended punch for scurvy, and seems to have been written deliberately to refute Lind's treatise.

63. James Lind, Treatise of the scurvy, bicentenary volume, Edinburgh University Press, 1953, p. 147.

64. David MacBride, An historical account of a new method of treating the scurvy at sea 


\section{William Buchan: medicine laid open}

which shews that this destructive disease may be easily and effectually cured without the aid of a fresh vegetable diet, London, A. Millar \& T. Cadell, 1767.

65. Buchan, op. cit., note 1 above, p. 50.

66. C. Lloyd, 'The introduction of lemon juice as a cure for scurvy', Bull. Hist. Med., 1961, 35: 123-132.

67. H. A. Waldron, 'The Devonshire colic', J. Hist. Med., 1970, 25: 383-413.

68. Anton von Stoerck, Libellus quo demonstratur cicutam non solum usu interno tutissime exhiberi, sed et esse simul remedium valde utile in multis morbis, qui hucusque curatu impossibiles dicebantur, Vienna, J. T. Trattner, 1760-1764.

69. Robert Whytt, Observations on the dropsy in the brain, Edinburgh, J. Balfour, 1768.

70. Francis Home, Medical facts and experiments, London, A. Millar, 1759, pp. 266-288.

71. J. Enders, 'Francis Home and his experimental approach to medicine', Bull. Hist. Med., 1964, 38: 101-112.

72. John Wesley, Primitive physic, or an easy and natural method of curing most diseases, 13th ed., Bristol, W. Pine, 1768, p. xxvii.

73. Buchan, op. cit., note 1 above, p. 152.

74. Max Neuburger, Die Lehre von die Heilkraft der Nature, Stuttgart, Ferdinand Enke, 1926, pp. 59-126.

75. Ibid., p. 17, Neuburger quotes this as the doctrine of Rufus of Ephesus who was the foremost representative of the school of pneumatists.

76. Buchan, op. cit., note 1 above, p. 231.

77. See for instance, Richard Mead, $A$ discourse on the smallpox and measles, London, J. Brindley, 1748, pp. 13-31.

78. Buchan, op. cit., note 1 above, p. 236.

79. Thomas Fuller, Exanthematologia, London, C. Rivington \& S. Austen, 1730, p. 222.

80. John Huxham, An essay on fevers, London, S. Austen, 1750, p. 162.

81. H. Boerhaave, Aphorismi de cognoscendis et curandis morbis, Leyden, J. Van der Linden, 1715 , p. 324.

82. Mead, op. cit., note 77 above, p. 40.

83. Buchan, op. cit., note 1 above, pp. 245-247.

84. See G. Miller, The adoption of inoculation for smallpox in England and France, Philadelphia, University of Pennsylvania Press, 1957, p. 155.

85. A. Monro, 'Account of the inoculation of the smallpox in Scotland', in The works of Alexander Monro, Edinburgh, C. Elliot \& G. Robinson, 1781, p. 681.

86. La Mettrie, Oeuvres philosophiques, Amsterdam, 1774, vol. 3, pp. 54-55, quoted in A. Vartanian, Diderot and Descartes, New Jersey, Princeton University Press, 1953, p. 303.

87. A. Jeffrey, An historical and descriptive account of Roxburghshire, Edinburgh, Fraser, 1836, p. 420.

88. D. Sage, Memorabilia domestica, or parish life in the north of Scotland, Wick, W. Rae, 1889, p. 179. Sage was referring to the period around the end of the eighteenth century.

89. Scots Mag., 1772, 34: 558.

90. Universal Mag., 1772, 51: 268.

91. Thomas Beddoes, Hygeia, or essays moral and medical, Bristol, R. Phillips, 1802, vol. 1, essay 2, p. 20.

92. Richard Reece, A practical dictionary of domestic medicine, London, Longman, Hurst, Rees \& Orme, 1808, p. 20.

93. Buchan, op. cit., note 1 above, 14th ed., " . . . with an appendix containing a complete treatise on the art of farriery; with directions for the purchasers of horses, and practical receipts for the cure of distempers incident to horses, cattle, sheep and swine", New Haven, N. Whiting, 1816. 